\title{
Epidemiological of and risk factors for Alzheimer's disease: A review
}

\author{
Jana Povova ${ }^{a}$, Petr Ambroz ${ }^{\mathrm{a}}$, Michal Bar ${ }^{\mathrm{b}}$, Veronika Pavukovaa ${ }^{\mathrm{a}}$, Omar Seryc, Hana Tomaskovaa ${ }^{\mathrm{a}}$, Vladimir Janout ${ }^{\mathrm{a}}$
}

\begin{abstract}
Background. Alzheimer's disease (AD) is the most common form of dementia. It is a degenerative, incurable and terminal disease. The increasing prevalence of $A D$ is, among other reasons, due to population aging, which is, to a certain extent, seen worldwide. Continuous advances in health care keep increasing life expectancy. Official statistics are likely to significantly underestimate the actual prevalence of AD. Alzheimer's disease represents an important public health problem. Its aetiology is still unknown and for this reason, it is necessary to study all potential risk factors which may contribute to the development of this disease.

Methods. We searched original and review articles addressing Alzheimer's disease using key words Alzheimer's disease, epidemiology, risk factors and prevention. We found and used one hundred and four references.

Conclusions. Based on epidemiological studies, genetic studies, neuroimaging methods and neuropathology research, three basic etiological hypotheses of the development of AD have been formulated: genetic, vascular and psychosocial. At present, the level of evidence is insufficient for the etiological role of other factors, such as nutrition, occupational exposure to various substances and inflammation. From the point of view of early diagnosis and application of primary or secondary prevention principles, genetic factors are the most important.
\end{abstract}

Key words: Alzheimer's disease, epidemiology, risk factors, prevention

Received: September 9, 2011; Accepted with revision: May 17, 2012; Available online: June 14, 2012 http://dx.doi.org/10.5507/bp.2012.055

aDepartment of Epidemiology and Public Health, Faculty of Medicine, University of Ostrava, Czech Republic
'Department of Clinical Studies, Faculty of Medicine, University of Ostrava
'Department of Biochemistry, Faculty of Science, Masaryk University Brno
Corresponding author: Jana Povova, e-mail: Jana.povova@osu.cz

\section{INTRODUCTION}

Alzheimer's disease (AD) is the most common form of dementia. It is a degenerative, incurable and terminal disease. Although it is mostly diagnosed in people over 65 years, a less prevalent early-onset form may develop much earlier.

Alzheimer's disease affects most (up to 75\%) of the more than 35 million people suffering from dementia worldwide. The prevalence is believed to double every 20 years. Thus, it is estimated that approximately 115 million people may be affected by AD in 2050. The disease has a major impact not only on the sufferers but also on persons caring for them as well as the entire society.

The etiological factors are mostly unknown. There is increasing evidence of the role that certain risk factors play in the development of the disease, such as genetic and vascular factors or disorders. Also known are psychosocial factors which may positively influence the pathogenesis and clinical manifestation of the disease. Therefore, intervention in these areas may lower the risk of its development or at least delay the clinical manifestation.

The increasing prevalence of $\mathrm{AD}$ is, among other reasons, due to population aging, which is, to a certain extent, seen worldwide.

\section{OCCURRENCE}

Prevalence

Aggregate data from studies on the prevalence of AD in Europe reported the age-standardized prevalence of AD in people aged 65 or more to be $4.4 \%$ (ref. ${ }^{1}$ ). A US study performed in a representative sample of persons over 70 years of age reported AD prevalence of $9.7 \%$ (ref. $^{2}$ ). The global prevalence of AD is estimated at $3.9 \%$ in people older than 60 years, with regional variations in individual continents ${ }^{3}$.

In developed countries, approximately 1 in 10 persons over 65 years of age suffers from a form of dementia compared with more than one third of those older than 85 years $^{4,5}$.

\section{Incidence}

Two US studies of persons aged 65 or more reported an AD incidence of 15.0 per 1,000 person-years. The incidence rates for males and females were 13.0 and 16.9 per 1,000 person-years, respectively ${ }^{6,7}$.

In a 3 year follow-up, a Swedish prospective study involving 987 persons aged 75 years or older found the incidence rates of dementia in the age group of 75-79 years to be 19.6 and 12.4 per 1,000 person-years in females and males, respectively. In those aged 90 or more, the incidence rates of dementia were 86.7 per 1,000 personyears in females and 15.0 per 1,000 person-years in males. 
A similar distribution by age and gender was seen in AD. The risk of the development of any form of dementia is reported to be approximately twice as high in females as in males and the risk of Alzheimer's disease is as much as three times higher in females ${ }^{8}$.

Numerous other studies report the incidence rates of dementia and $\mathrm{AD}$ as the number of persons per year.

For example, in a British prospective cohort study of 1,070 persons aged 65 or more and followed for 3 years, the incidence of all types of dementia was 9.2 per 1,000 population and year, of which the AD incidence was 6.3 per 1,000 population and year ${ }^{9}$.

Koukolík reported approximately 35,000 AD patients aged 65 years or more in former Czechoslovakia in 1983 (ref. $\left.{ }^{10}\right)$.

According to the Czech Alzheimer Society, approximately 130,000 people in the Czech Republic currently suffer from dementia, two thirds of which have AD.

\section{RISK FACTORS}

\section{Hypotheses}

Based on epidemiological studies, neuroimaging methods and neuropathology research, three etiological hypotheses of the development have been reported, with moderate or strong evidence ${ }^{11}$ :

- genetic,

- vascular, and

- psychosocial.

At present, the level of evidence is insufficient for the etiological role of other factors, such as nutrition, occupational exposure to various substances and inflammation.

\section{Genetic hypothesis}

Early-onset familial AD is usually caused by autosomal dominant mutations in the genes for amyloid precursor protein (APP), presenilin 1 and presenilin 2. This form of AD accounts for approximately $2-5 \%$ of all AD cases ${ }^{12}$.

First-degree relatives of patients with $\mathrm{AD}$ are at higher lifetime risk of developing the disease than the rest of the population ${ }^{13}$. Both genetic and other factors contribute to the increased risk and familial aggregation of AD cases. As far as genetic factors are concerned, this risk may be partly due to the presence of the apolipoprotein E (APOE) apoE4 allele. Other genes also contribute to the pathogenesis of this mental disorder ${ }^{14}$. The apoE4 allele is the only proven genetic factor so far identified in the development of both the early- and late-onset forms of $\mathrm{AD}$. This factor increases susceptibility to AD but it is neither necessary nor sufficient for the development of this disease. The higher the number of the apoE4 alleles, the higher the risk of $\mathrm{AD}$ and the lower the age of onset. The risk effect of the presence of the apoE4 allele decreases with age. Generally, approximately $15-20 \%$ of $\mathrm{AD}$ cases may be attributed to this risk ${ }^{15}$.

Tens of other candidate genes with polymorphisms affecting the risk of the development of $\mathrm{AD}$ have been studied. Predominantly, these are secretase genes - e.g.
BACE1 (beta-site amyloid precursor protein-cleaving enzyme 1), presenilin 1, peptidase genes - e.g. ECE1 (endothelin-converting enzyme), IDE (insulin-degrading enzyme), microtubule and cytoskeletal genes - e.g. MAPT (microtubule-associated protein tau), synaptic genes - e.g. ABCA1 (ATP-binding cassette A1 transporter), anti-apoptotic genes - e.g. IL-1 (interleukin 1), protease genes -e.g. ACE (angiotensin-converting enzyme) and other genes such as the gene for APP.

\section{Vascular hypothesis}

Vascular risk factors, such as smoking, obesity and high total cholesterol levels, together with vascular morbidity, such as hypertension, diabetes mellitus and asymptomatic cerebral infarction, are associated with a higher risk of dementia including Alzheimer's disease.

\section{Smoking}

Earlier cross-sectional studies often reported a lower prevalence of AD among smokers compared with nonsmokers ${ }^{16}$. This seemingly protective effect was probably due to survivor bias since the proportion of smokers among the prevalent cases was smaller.

When incident cases of AD were studied, however, the situation was completely reversed ${ }^{17-19}$. That is, numerous analytical studies found a significantly increased risk of AD associated with cigarette smoking, especially in apoE4 allele non-carriers ${ }^{20-22}$. Meta-analyses of these analytical studies concluded that current smoking was associated with an increased risk of the development of AD, with $\mathrm{RR}=1.79$; 95\% CI 1.43-2.23 (ref. ${ }^{23,24)}$.

\section{Alcohol}

It is well recognized that alcohol abuse causes alcohol dementia. Moreover, middle-aged heavy drinkers, especially apoE4 allele carriers, were found to have a more than 3-fold higher risk of dementia and AD later in their lives $^{25}$. On the other hand, the risk of developing dementia and AD was reduced in light and moderate alcohol consumers $^{26,27}$.

In heavy consumers, alcohol clearly damages the brain. Even light to moderate alcohol consumption was found to be related to brain atrophy and volume loss ${ }^{28,29}$.

\section{Overweight and obesity}

Higher BMI in middle age is a risk factor for AD and other dementias. Higher BMI or obesity (in particular abdominal obesity) at around the age of 50 years means an increased risk of dementia 20-25 years later ${ }^{30-33}$. Several analytical studies in the elderly suggested that a significant decrease in BMI was associated with a higher risk of AD in the following 5-6 years ${ }^{37,38}$.

Blood pressure and management of hypertension

Increased blood pressure in middle age, especially if uncontrolled, was associated with a higher risk of the later development of AD in several observational studies ${ }^{39,40}$.

Findings from analytical studies of the association between blood pressure and the risk of dementia are not 
consistent. Studies with a relatively short follow-up (less than 3 years) found no or even an inverse association between blood pressure values and the risk of dementia and $\mathrm{AD}$ (ref. ${ }^{41}$ ). Since dementia has a long latent period and blood pressure may drop in its pre-clinical stage, an absent or inverse association may be interpreted as a result of the process ${ }^{42,43}$.

However, analytical studies with a longer follow-up (e.g. more than 6 years) reported an inverse association $^{44-46}$, suggesting that low blood pressure later in the life may contribute to the development or clinical manifestation of dementia including AD ( ref. $^{41,47}$ ).

Longitudinal studies have repeatedly shown a protective effect of antihypertensive drugs against the development of dementia and AD (ref. ${ }^{41,48,49}$ ). Recent analytical studies have suggested that the protective effect of antihypertensive therapy may depend on its duration and the patient's age. Greater protective effects were found in the younger elderly (e.g. under 75 years of age) and in those with long-term treatment ${ }^{50,51}$. Antihypertensive therapy may protect against dementia and AD by delaying the atherosclerotic process, decreasing the number of atherosclerotic lesions and improving cerebral perfusion ${ }^{41}$.

\section{Hypercholesterolemia and statin therapy}

High total serum cholesterol levels in middle age were found to be a risk factor for the development of $\mathrm{AD}$ at a later age $\mathrm{e}^{52,53}$. High total cholesterol in middle age is a risk factor for the development of $\mathrm{AD}$ and other dementias 20 years later but decreasing serum cholesterol levels in late middle age may be due to ongoing disease processes and may represent a marker for later $\mathrm{AD}$ and other dementias ${ }^{54}$.

According to several cross-sectional and case-control studies, the use of statins significantly decreases the prevalence of AD (ref. ${ }^{55,56}$ ). Whereas an analytical study (the Rotterdam Study) showed that the use of statins was associated with a lower risk of $\mathrm{AD}\left(\right.$ ref. $\left.^{57}\right)$, other prospective studies found either no beneficial effect or only a slightly decreased risk of $\mathrm{AD}$ related to the use of statins ${ }^{58,59}$. Experimental studies have suggested that statins may decrease the production of beta amyloid both in vitro and in vivo. Statins also have various other effects that may be beneficial for the CNS and thus may lower the risk of AD.

\section{Nutritional factors}

Several analytical studies showed a decreased risk of $\mathrm{AD}$ associated with higher intake of antioxidants such as vitamins $\mathrm{E}$ and $\mathrm{C}$ (ref. ${ }^{60,61}$ ), either in the diet or in dietary supplements. However, some studies found a negative effect $^{62}$. Yet other studies showed that the Mediterranean diet (high intake of fish, fruit and vegetables rich in antioxidants) was associated with a lower risk of $\mathrm{AD}$, independent of vascular risk factors ${ }^{63,64}$. A Cochrane systematic review concluded that supplementation with folic acid and vitamin B12 had no beneficial effect on cognitive functions despite the fact that folic acid and vitamin B12 effectively decrease serum homocysteine levels ${ }^{65}$.

It was also reported that a diet rich in saturated fats and cholesterol increased the risk of AD (ref. ${ }^{66}$ ) whereas polyunsaturated fatty acids and fish may be protective against dementia ${ }^{67,68}$.

\section{Diabetes mellitus}

Many longitudinal studies found an increased risk of not only neurodegenerative but also vascular dementia in people with diabetes ${ }^{69-71}$. This risk was confirmed by a systematic review ${ }^{72}$. The presence of diabetes in middle age or a longer duration of diabetes may play a key role in the development of $\mathrm{AD}$ and other dementias ${ }^{73,74}$. Moreover, borderline conditions, prediabetes or impaired glucose tolerance are also related to an increased risk of AD and other dementias in very old people ${ }^{75}$. This relationship may be partly explained by diabetic comorbidities such as hypertension and dyslipidaemia ${ }^{76-78}$.

A relationship was also found between a higher prevalence of AD in an elderly population in Finland ${ }^{79}$, although an analytical study of a multiethnic cohort of the elderly in the USA found no association between the metabolic syndrome and either the prevalence or incidence of $\mathrm{AD}$, despite the fact that two components of the syndrome, i.e. diabetes and hyperinsulinaemia, were associated with increased risk of incident $\mathrm{AD}\left(\right.$ ref. $\left.{ }^{80}\right)$.

Cardiovascular and cerebrovascular diseases

A significantly increased risk of dementia and $\mathrm{AD}$ was found in patients who had suffered a stroke as well as clinically silent cerebral infarction confirmed by magnetic resonance imaging ${ }^{81,82}$.

Also cardiovascular diseases are associated with an increased incidence of dementia and $\mathrm{AD}$, with the highest risk of dementia in persons with peripheral artery disease, suggesting that extensive peripheral atherosclerosis is a risk factor for $\mathrm{AD}$ ( ref. $^{83,84}$ ).

Neuropathological studies have suggested that cerebrovascular lesions, atherosclerosis and neurodegenerative changes often coexist with each other in the brain, producing a clinical manifestation of the dementia syndrome ${ }^{85,86}$.

\section{Psychosocial hypothesis}

A systematic review found that psychosocial factors and an active lifestyle throughout life may decrease the risk of dementias including $\mathrm{AD}\left(\right.$ ref. $\left.^{87}\right)$.

\section{Education and socioeconomic status}

Lower education is tied to increased risk of dementia and AD. This link has been confirmed by many crosssectional and longitudinal studies ${ }^{88,89}$. Although education and socioeconomic status are highly correlated with each other, when studied separately, an independent association was only found for education ${ }^{90}$.

\section{Social network and social engagement}

Longitudinal observational studies suggest that a poor social network or a lack of social engagement are associated with decreased cognitive functions and dementia ${ }^{87,91}$. The risk of dementia was also higher in elderly persons with increased social isolation and less frequent and unsatisfactory contacts with relatives and friends. Persons with low neuroticism combined with high extraversion 
had a lower risk of dementia ${ }^{92}$. Low levels of social engagement in late life and decreased social engagement from middle to late life were associated with a two-fold increase in the risk of the development of dementia and $\mathrm{AD}$ later in life $\mathrm{e}^{93,94}$.

\section{Physical activity}

Regular physical exercise is associated with a delay in onset of dementia and AD in the elderly without cognitive impairment ${ }^{95}$. Physical activity in the form of various leisure activities rather than sports or specific physical exercise led to a decrease in the risk of dementia ${ }^{96}$. Even low-intensity physical activity such as walking may lower the risk of dementia and cognitive impairment ${ }^{97}$. A significant protective effect of regular physical activity in middle age, with respect to the development of dementia and $\mathrm{AD}$ later in the life, was found especially in persons with the apoE4 allele ${ }^{98}$.

\section{Mental activity}

Various activities requiring a mental effort, such as reading, social and cultural activities, knitting, gardening, dancing, tabletop games, playing musical instruments, watching specific TV programmes, showed a protective effect against dementia and $\mathrm{AD}$ (ref. ${ }^{99,72}$ ). A study of Swedish twins showed that complexity of work, in particular more complex work with people, may reduce the risk of $\mathrm{AD}$ ( ref. ${ }^{100}$ ). A recent neuroimaging study sug gested that a high level of complex mental activity across the lifespan was correlated with reduced hippocampal atrophy ${ }^{101}$.

\section{PREVENTION}

\section{Primary prevention}

Although the mechanisms of action of vascular and psychosocial factors participating in the pathogenesis and clinical manifestation of AD have not been fully understood, primary prevention is possible since most vascular and psychosocial factors including lifestyle factors are modifiable ${ }^{11,102}$.

Primary prevention strategies addressing the vascular pathway in the development of AD include:

- measures against hypertension, obesity, increased glucose levels and diabetes mellitus in middle age,

- measures against cardiac failure and preventing very low blood pressure and thus maintaining sufficient cerebral perfusion.

Primary prevention strategies focused on maintaining an active and socially integrated lifestyle:

- ensuring an extensive social network,

- frequent participation in social physical and intellectual stimulating activities ${ }^{11,87}$.

\section{Secondary prevention}

$\mathrm{AD}$ is characterized by a pre-clinical stage lasting several years during which progressive neurodegenerative changes occur in the brain, even before the onset of typical clinical signs ${ }^{103}$. However, this pre-clinical stage is difficult to identify although some clinical markers, neuroimaging biomarkers and biochemical markers are available ${ }^{104}$ :

- mild cognitive impairment (isolated memory loss),

- biochemical markers in the serum and cerebrospinal fluid (beta amyloid and tau protein),

- neuroimaging methods are considered an effective tool for diagnosing $\mathrm{AD}$ in the pre-clinical stage (amyloid positron emission tomography is able to measure beta amyloid in the brain in vivo),

- volumetric magnetic resonance imaging detecting medial temporal lobe atrophy.

\section{Tertiary prevention}

The goal of tertiary prevention of AD is to rule out functional disability and, if possible, improve the quality of life:

- cognitive training,

- treatment with cholinesterase inhibitors (donepezil, rivastigmine, galantamine),

- treatment with N-methyl D-aspartate receptor antagonists (memantine).

\section{CONCLUSION}

Alzheimer's disease represents an important public health problem. Its aetiology is still unknown and for this reason, it is necessary to study all potential risk factors which may contribute to its development.

From the point of view of early diagnosis and potential application of primary or secondary prevention, genetic factors are the most important.

\section{ABBREVIATIONS}

AD, Alzheimer's disease.

\section{ACKNOWLEDGMENT}

Supported by the Czech Ministry of Health grant project no. NT11152-6/2010.

\section{CONFLICT OF INTEREST STATEMENT}

Author's conflict of interest diclosure: The authors stated that there are no conflicts of interest regarding the publication of this article.

\section{REFERENCES}

1. Lobo A, Launer LJ, Fratiglioni L, Andersen K, Di Carlo A, Breteler MM, Copeland JR, Dartigues JF, Jagger C, Martinez-Lage J, Soininen H, Hofman A. Prevalence of dementia and major subtypes in Europe: A collaborative study of population-based cohorts. Neurology 2000;54:54-9. 
2. Plassman BL, Langa KM, Fischer GG, Heeringa SG, DR Weir, Ofstedal MB, Burke JR, Hurd MD, Potter GG, Rodgers WL, Steffens DC, Willis RJ, Wallace RB. Prevalence of dementia in the United States: the aging, demographics, and memory study. Neuroepidemiology 2007;29:125-32.

3. Ferri $C P$, Prince $M$, Brayne $C$, Brodaty $H$, Fratiglioni L, Ganguli $M$, Hall K, Hasegawa K, Hendrie H, Huang Y, Jorm A, Mathers C, Menezes PR, Rimmer E, Scazufca M. Global prevalence of dementia: a Delph consensus study. Lancet 2005;366:2112-7.

4. von Strauss E, Viitanen M, De Ronchi D, Winblad B, Fratiglioni L. Aging and the occurrence of dementia: findings from a populationbased cohort with a large sample of nonagenarians. Arch Neurol 1999;56:587-92.

5. Corrada MM, Brookmeyer R, Berlau D, Paganini-Hill A, Kawas $C H$. Prevalence of dementia after age 90: results from The 90+ Study. Neurology 2008;71:337-43.

6. Kawas C, Gray S, Brookmeyer R, Fozard J, Zonderman A. Age-specific incidence rates of Alzheimer's disease: the Baltimore Longitudina Study of Aging. Neurology 2000;54:2072-7.

7. Kukull WA, Higdon R, Bowen JD, McCormick WC, Teri L, Schellenberg GD, van Belle G, Jolley L, Larson EB. Dementia and Alzheimer disease incidence: a prospective cohort study. Arch Neurol 2002;59:1737-46.

8. Fratiglioni $L$, Viitanen $M$, von Strauss $E$, Tontodonati V, Herlitz A, Winblad B. Very old women at highest risk of dementia and Alzheimer's disease: Incidence data from the Kungnsholmen Project, Stockholm. Neurology 1997;48,132-8.

9. Copeland JRM, Davidson IA, Dewey ME Gilmore C, Larkin BA, McWilliam C, Saunders PA, Scott, Sharma V, Sullivan C. Alzheimer 's disease other dementias, depression and pseudodementia: Prevalence, Incidence and Three Year Outcome in Liverpool. Br J Psychiatry 1992;161,230-9.

10. Koukolík F., Jirák R. Alzheimerova nemoc a další demence, Galén,1998.

11. Fratiglioni L, von Strauss E, Qiu CX. Epidemiology of the dementias of old age. In Dening T, Jacoby R, Oppenheimer C, Thomas A, eds. The Oxford Textbook of Old Age Psychiatry. 4th ed. New York, NY: Oxford University Press 2008;391-406.

12. Blennow K, de Leon MJ, Zetterberg H. Alzheimer's disease. Lancet 2006;368:387-403.

13. Green RC, Cupples LA, Go R, Benke KS, Edeki T, Griffith PA, Williams M, Hipps Y, Graff-Radford N, Bachman D, Farrer LA.Risk of dementia among white and African American relatives of patients with Alzheimer disease. JAMA 2002;287:329-36.

14. Huang W, Qiu C, von Strauss E, Winblad B, Fratiglioni L. APOE genotype, family history of dementia, and Alzheimer disease risk: a 6-year follow-up study. Arch Neurol 2004;61:1930-4.

15. Qiu C, Kivipelto M, Agüero-Torres H, Winblad B, Fratiglioni L. Risk and protective effects of the APOE gene towards Alzheimer's dis ease in the Kungsholmen project: variation by age and sex. J Neurol Neurosurg Psychiatry 2004;75:828-33.

16. Fratiglioni L, Wang HX. Smoking and Parkinson's and Alzheimer's disease: review of the epidemiological studies. Behav Brain Res 2000;113:117-20.

17. Wang HX, Fratiglioni L, Frisoni GB, Viitanen M, Winblad B. Smoking and the occurrence of Alzheimer's disease: cross-sectional and longitudinal data in a population-based study. Am J Epidemio 1999;149:640-4.

18. Hill G, Connelly J, Hébert R, Lindsay J, Millar W. Neyman®s bias revisited. J Clin Epidemiol 2003;56:293-6.

19. Tyas SL, White LR, Petrovitch H, Webster Ross G, Foley DJ, Heimovitz HK, Launer LJ. Mid-life smoking and late-life dementia: the HonoluluAsia Aging Study. Neurobiol Aging 2003;24:589-96.

20. Ott A, Slooter AJ, Hofman A, van Harskamp F, Witteman JC, Van Broeckhoven C, van Duijn CM, Breteler MM. Smoking and risk of dementia and Alzheimer's disease in a population-based cohort study: the Rotterdam Study. Lancet 1998;351:1840-3.

21. Merchant C, Tang MX, Albert S, Manly J, Stern Y, Mayeux R. The influ- ence of smoking on the risk of Alzheimer's disease. Neurology 1999;52:1408-12.

22. Aggarwal NT, Bienias JL, Bennett DA, Wilson RS, Morris MC, Schneider JA, Shah RC, Evans DA. The relation of cigarette smoking to incident Alzheimer's disease in a biracial urban community population. Neuroepidemiology 2006;26:140-6.
23. Anstey KJ, von Sanden C, Salim A, O'Kearney R. Smoking as a risk fac- tor for dementia and cognitive decline: a meta-analysis of prospective studies. Am J Epidemiol 2007;166:367-78.

24. Peters R, Poulter R, Warner J, Beckett N, Burch L, Bulpitt C. Smoking, dementia and cognitive decline in the elderly, a systematic review. BMC Geriatr 2008;8:36.

25. Anttila T, Helkala EL, Viitanen $M$, Kåreholt I, Fratiglioni L, Winblad B, Soininen $\mathrm{H}$, Tuomilehto J, Nissinen A, Kivipelto M. Alcohol drinking in middle age and subsequent risk of mild cognitive impairment and dementia in old age: a prospective population based study. BMJ 2004;329:539.

26. Huang W, Qiu C, Winblad B, Fratiglioni L. Alcohol consumption and incidence of dementia in a community sample aged 75 years and older. J Clin Epidemiol 2002;55:959-64.

27. Ruitenberg A, van Swieten JC, Witteman JC, Mehta KM, van Duijn CM, Hofman A, Breteler MM. Alcohol consumption and risk of dementia: the Rotterdam Study. Lancet 2002;359:281-6.

28. Ding J, Eigenbrodt ML, Mosley TH Jr, Hutchinson RG, Folsom AR, Harris TB, Nieto FJ. Alcohol intake and cerebral abnormalities on magnetic resonance imaging in a community-based population of middle-aged adults: the Atherosclerosis Risk in Communities (ARIC) study. Stroke 2004;35:16-21.

29. Paul CA, Au R, Fredman L, Massaro JM, Seshadri S, Decarli C, Wolf PA. Association of alcohol consumption with brain volume in the Framingham study. Arch Neurol 2008;65:1363-7.

30. Kivipelto $M$, Ngandu T, Fratiglioni L, M Viitanen, Kåreholt I, Winblad B, Helkala EL, Tuomilehto J, H Soininen, Nissinen A. Obesity and vascular risk factors at midlife and the risk of dementia and Alzheimer disease. Arch Neurol 2005;62:1556-60.

31. Rosengren A, Skoog I, Gustafson D, Wilhelmsen L. Body mass index, other cardiovascular risk factors, and hospitalization for dementia. Arch Intern Med 2005;165:321-6.

32. Whitmer RA, Gunderson EP, Barrett-Connor E, Quesenberry CP Jr., Yaffe K. Obesity in middle age and future risk of dementia: a 27 year longitudinal population based study. BMJ 2005;330:1360.

33. Fitzpatrick AL, Kuller LH, Lopez OL, Diehr P, O'Meara ES, Longstreth WT Jr, Luchsinger JA. Midlife and late-life obesity and the risk of dementia : cardiovascular health study. Arch Neurol 2009;66:336-42.

34. Buchman AS, Wilson RS, Bienias JL, Shah RC, Evans DA, Bennett DA Change in body mass index and risk of incident Alzheimer disease. Neurology 2005;65:892-7.

35. Johnson DK, Wilkins CH, Morris JC. Accelerated weight loss may precede diagnosis in Alzheimer disease. Arch Neurol 2006;63:1312-7.

36. Dahl AK, Löppönen M, Isoaho R, Berg S, Kivelä SL. Overweight and obesity in old age are not associated with greater dementia risk. J Am Geriatr Soc 2008;56:2261-66.

37. Nourhashemi F, Deschamps V, Larrieu S, Letenneur L, Dartigues JF, Barberger-Gateau P. Body mass index and incidence of dementia: the PAQUID study. Neurology 2003;60:117-9.

38. Atti AR, Palmer K, Volpato S, Winblad B, De Ronchi D, Fratiglioni L. Late-life body mass index and dementia incidence: nine-year follow-up data from the Kungsholmen Project. J Am Geriatr Soc 2008;56:111-6.

39. Launer LJ, Ross GW, Petrovitch H, Masaki K, Foley D, White LR, Havlik RJ. Midlife blood pressure and dementia: the Honolulu-Asia aging study. Neurobiol Aging 2000;21:49-55.

40. Kivipelto $M$, Helkala EL, Laakso MP, Hänninen T, Hallikainen $M$, Alhainen $\mathrm{K}$, Soininen $\mathrm{H}$, Tuomilehto J, Nissinen A. Midlife vascular risk factors and Alzheimer's disease in later life: longitudinal, population based study. BMJ 2001;322:1447-51.

41. Qiu C, Winblad B, Fratiglioni L. The age-dependent relation of blood pressure to cognitive function and dementia. Lancet Neurol 2005;4:487-99.

42. Skoog I, Lernfelt B, Landahl S, Palmertz B, Andreasson LA, Nilsson L, Persson G, Odén A, Svanborg A. 15-year longitudinal study of blood pressure and dementia. Lancet 1996;347:1141-5.

43. Petitti DB, Crooks VC, Buckwalter JG, Chiu V. Blood pressure levels before dementia. Arch Neurol 2005;62:112-6.

44. Morris MC, Scherr PA, Hebert LE, Glynn RJ, Bennett DA, Evans DA Association of incident Alzheimer disease and blood pressure measured from 13 years before to 2 years after diagnosis in a large community study. Arch Neurol 2001;58:1640-6.

45. Qiu C, von Strauss E, Fastbom J, Winblad B, Fratiglioni L. Low blood pressure and risk of dementia in the Kungsholmen project: a 6-year follow-up study. Arch Neurol 2003;60:223-8. 
46. Verghese J, Lipton RB, Hall CB, Kuslansky G, Katz MJ. Low blood pressure and the risk of dementia in very old individuals. Neurology 2003;61:1667-72.

47. Ruitenberg A, den Heijer T, Bakker SL, van Swieten JC, Koudstaal PJ, Hofman A, Breteler MM. Cerebral hypoperfusion and clinical onset of dementia: the Rotterdam Study. Ann Neurol 2005;57:789-94.

48. Yasar S, Corrada M, Brookmeyer R, Kawas C. Calcium channel blockers and risk of AD: the Baltimore Longitudinal Study of Aging Neurobiol Aging 2005;26:157-63.

49. Khachaturian AS, Zandi PP, Lyketsos CG, Hayden KM, Skoog I, Norton MC, Tschanz JT, Mayer LS, Welsh-Bohmer KA, Breitner JC. Antihypertensive medication use and incident Alzheimer disease: the Cache County Study. Arch Neurol 2006;63:686-92.

50. Peila R, White LR, Masaki K, Petrovitch H, Launer LJ. Reducing the risk of dementia: efficacy of long-term treatment of hypertension. Stroke 2006;37:1165-70.

51. Haag MD, Hofman A, Koudstaal PJ, Breteler MM, Stricker BH. Duration of antihypertensive drug use and risk of dementia. A prospective cohort study. Neurology 2009;72:1727-34

52. Kivipelto $M$, Helkala $E L$, Laakso $M P$, Hänninen $T, M$ Hallikainen Alhainen K, livonen S, Mannermaa, Tuomilehto J, Nissinen, Soininen H. Apolipoprotein E Â4 allele, elevated midlife total cholesterol level, and high midlife systolic blood pressure are independent risk factors for late-life Alzheimer disease. Ann Intern Med 2002;137:149-55.

53. Whitmer RA, Sidney S, Selby J, Johnston SC, Yaffe K. Midlife cardiovascular risk factors and risk of dementia in late life. Neurology 2005;64:277-81.

54. Solomon A, Kåreholt I, Ngandu T, Winblad B, Nissinen, Tuomilehto J, H Soininen, Kivipelto M. Serum cholesterol changes after midlife and late-life cognition: twenty-one-year follow-up study. Neurology 2007;68:751-6.

55. Jick H, Zornberg GL, Jick SS, Seshadri S, Drachman DA. Statins and the risk of dementia. Lancet 2000;356:1627-31.

56. Rockwood K, Kirkland S, Hogan DB, MacKnight C, Merry H, Verreault $\mathrm{R}$, Wolfson C, McDowell I. Use of lipid-lowering agents, indication bias, and the risk of dementia in community-dwelling elderly people. Arch Neurol 2002;59:223-7.

57. Haag MD, Hofman A, Koudstaal PJ, Stricker BH, Breteler MM. Statins are associated with a reduced risk of Alzheimer disease regardless of lipophilicity: the Rotterdam Study. J Neurol Neurosurg Psychiatry 2009;80:13-7.

58. Rea TD, Breitner JC, Psaty BM, Fitzpatrick AL, Lopez OL, Newman AB, Hazzard WR, Zandi PP, Burke GL, Lyketsos CG, Bernick C, Kulle $\mathrm{LH}$. Statin use and the risk of incident dementia: the Cardiovascular Health Study. Arch Neurol 2005;62:1047-51.

59. Zandi PP, Sparks DL, Khachaturian AS, Khachaturian AS, Tschanz J, Norton M, Steinberg M, Welsh-Bohmer KA, Breitner JC. Do statins reduce risk of incident dementia and Alzheimer disease? The Cache County Study. Arch Gen Psychiatry 2005;62:217-24.

60. Zandi PP, Anthony JC, Khachaturian AS, Stone SV, Gustafson D, Tschanz JT, Norton MC, Welsh-Bohmer KA, Breitner JC. Reduced risk of Alzheimer disease in users of antioxidant vitamin supplements: the Cache County Study. Arch Neurol 2004;61:82-8.

61. Barberger-Gateau P, Raffaitin C, Letenneur L, C Berr, Tzourio C, Dartigues JF, Alpérovitch A. et al. Dietary patterns and risk of dementia: the Three-City cohort study. Neurology 2007;69:1921-30.

62. Gray SL, Anderson ML, Crane PK, Breitner JC, McCormick W, Bowen JD, Teri L, Larson E. Antioxidant vitamin supplement use and risk of dementia or Alzheimer's disease in older adults. J Am Geriatr Soc 2008;56:291-5.

63. Scarmeas N, Stern Y, Mayeux R, Luchsinger JA. Mediterranean diet, Alzheimer disease, and vascular mediation. Arch Neurol 2006;63:1709-17.

64. Scarmeas N, Stern Y, Tang MX, Mayeux R, Luchsinger JA. Mediterranean diet and risk for Alzheimer's disease. Ann Neuro 2006;59:912-21.

65. Malouf M, Grimley EJ, Areosa SA. Folic acid with or without vitamin B12 for cognition and dementia. Cochrane Database Syst Rev 2003 CD004514.

66. Laitinen $\mathrm{MH}, \mathrm{Ngandu} \mathrm{T}$, Rovio S, Helkala EL, Uusitalo U, Viitanen M, Nissinen A, Tuomilehto J, Soininen $\mathrm{H}$, Kivipelto $M$. Fat intake at midlife and risk of dementia and Alzheimer's disease: a populationbased study. Dement Geriatr Cogn Disord 2006;22:99-107.
67. Huang TL, Zandi PP, Tucker KL, Fitzpatrick AL, Kuller LH, Fried LP, Burke GL, Carlson MC. Benefits of fatty fish on dementia risk are stronger for those without APOE e4. Neurology 2005;65:1409-14.

68. Schaefer EJ, Bongard V, Beiser AS, Lamon-Fava S, Robins SJ, Au R, Tucker KL, Kyle DJ, Wilson PW, Wolf PA. Plasma phosphatidylcholine docosahexaenoic acid content and risk of dementia and Alzheimer disease: the Framingham Heart Study. Arch Neurol 2006;63:1545-50.

69. Arvanitakis Z, Wilson RS, Bienias JL, Evans DA, Bennett DA. Diabetes mellitus and risk of Alzheimer disease and decline in cognitive function. Arch Neurol 2004;61:661-6.

70. Akomolafe A, Beiser A, Meigs JB, Au R, Green RC, Farrer LA, Wolf PA, Seshadri S. Diabetes mellitus and risk of developing Alzheimer disease: results from the Framingham Study. Arch Neurol 2006;63:15515.

71. Irie F, Fitzpatrick AL, Lopez OL, et al. Enhanced risk for Alzheimer disease in persons with type 2 diabetes and APOE e4: the Cardiovascular Health Study Cognition Study. Arch Neurol 2008;65:89-93.

72. Biessels GJ, Staekenborg S, Brunner E, Brayne C, Scheltens P. Risk of Dementia in diabetes mellitus: a systematic review. Lancet Neurol 2006;5:64-74

73. Roberts RO, Geda YE, Knopman DS, Christianson TJ, Pankratz VS, Boeve BF, Vella A, Rocca WA, Petersen RC. Association of duration and severity of diabetes mellitus with mild cognitive impairment. Arch Neurol 2008;65:1066-73.

74. Xu W, Qiu C, Gatz M, Pedersen NL, Johansson B, Fratiglioni L. Mid and late-life diabetes in relation to the risk of dementia: a population- based twin study. Diabetes 2009;58:71-7.

75. Xu WL, Qiu CX, Winblad B, Fratiglioni L. The effect of borderline dia- betes mellitus on the risk of dementia and Alzheimer disease. Diabetes 2007;56:211-6.

76. Korf ES, White LR, Scheltens $P$, Launer LJ. Brain aging in very old men with type 2 diabetes: the Honolulu-Asia Aging Study. Diabetes Care 2006;29:2268-74.

77. Rönnemaa E, Zethelius B, Sundelöf J, Sundström J, DegermanGunnarsson M, Berne C, Lannfelt L, Kilander L. Impaired insulin secretion increases the risk of Alzheimer disease. Neurology 2008;71:1065-71.

78. Xu WL, von Strauss E, Qiu CX, Winblad B, Fratiglioni L. Uncontrolled diabetes increases the risk of Alzheimer's disease: a populationbased cohort study. Diabetologia 2009;52:1031-9.

79. Vanhanen M, Koivisto K, Moilanen L, Helkala EL, Hänninen T, Soininen $\mathrm{H}, \mathrm{K}$ Kervinen, Kesäniemi YA, Laakso M, Kuusisto J. Association of metabolic syndrome with Alzheimer disease: a population-based study. Neurology 2006;67:843-7.

80. Muller M, Tang MX, Schupf N, Manly JJ, Mayeux R, Luchsinger JA. Metabolic syndrome and dementia risk in a multiethnic elderly cohort. Dement Geriatr Cogn Disord 2007;24:185-92.

81. Vermeer SE, Prins ND, den Heijer T, Hofman A, Koudstaal PJ, Breteler MM. Silent brain infarcts and the risk of dementia and cognitive decline. N Engl J Med 2003;348:1215-22.

82. Honig LS, Tang MX, Albert S, R Costa, Luchsinger J, J Manly, Stern Y, Mayeux R. Stroke and the risk of Alzheimer disease. Arch Neurol 2003;60:1707-12.

83. Newman $A B$, Fitzpatrick $A L$, Lopez $O$, Jackson $S$, Lyketsos $C$, Jagust $W$ Ives D, Dekosky ST, Kuller LH. Dementia and Alzheimer's disease incidence in relationship to cardiovascular disease in the Cardiovascular Health Study cohort. J Am Geriatr Soc 2005;53:1101-7.

84. Beeri MS, Rapp M, Silverman JM, Schmeidler J, Grossman HT, Fallon JT, Purohit DP, Perl DP, Siddiqui A, Lesser G, Rosendorff C, Haroutunian V. Coronary artery disease is associated with Alzheimer disease neuropathology in APOE4 carriers. Neurology 2006;66:13991404.

85. Snowdon DA, Greiner LH, Mortimer JA, Riley KP, Greiner PA, Markesbery WR. Brain infarction and the clinical expression of Alzheimer disease: the Nun Study. JAMA 1997;277:813-7.

86. Esiri MM, Nagy Z, Smith MZ, Barnetson L, Smith AD. Cerebrovascular disease and threshold for dementia in the early stages of Alzheimer's disease. Lancet 1999;354:919-20.

87. Fratiglioni L, Paillard-Borg S, Winblad B. An active and socially integrated lifestyle in late life might protect against dementia. Lancet Neurol 2004:3:343-53.

88. Qiu C, Bäckman L, Winblad B, Agüero-Torres H, Fratiglioni L. The influence of education on clinically diagnosed dementia: incidence and mortality data from the Kungsholmen Project. Arch Neurol 2001;58:2034-9. 
89. Ngandu T, von Strauss $E$, Helkala EL, Winblad B, Nissinen A, Tuomilehto J, Soininen $\mathrm{H}$, Kivipelto M. Education and dementia: what lies behind the association? Neurology 2007;69:1442-50.

90. Karp A, Kåreholt I, Qiu C, Bellander T, Winblad B, Fratiglioni L. Relation of education and occupation-based socioeconomic status to incident Alzheimer's disease. Am J Epidemiol 2004;159:175-83.

91. Fratiglioni L, Wang HX, Ericsson K, Maytan M, Winblad B. Influence of social network on occurrence of dementia: a community-based longitudinal study. Lancet 2000;355:1315-9.

92. Wang HX, Karp A, Herlitz A, Crowe M, Kåreholt I, Winblad B, Fratiglioni L. Personality and lifestyle in relation to dementia incidence. Neurology 2009;72:253-9.

93. Wang HX, Karp A, Winblad B, Fratiglioni L. Late-life engagement in social and leisure activities is associated with a decreased risk of dementia: a longitudinal study from the Kungsholmen project. Am J Epidemiol 2002;155:1081-7.

94. Saczynski JS, Pfeifer LA, Masaki K, Korf ES, Laurin D, White L, Launer LJ. The effect of social engage- ment on incident dementia: the Honolulu-Asia Aging Study. Am J Epidemiol 2006;163:433-40.

95. Larson EB, Wang L, Bowen JD, McCormick WC, Teri L, Crane P Kukull W. Exercise is associated with reduced risk for incident dementia among persons 65 years of age and older. Ann Intern Med 2006;144:73-81.

96. Karp A, Paillard-Borg S, Wang HX, Silverstein M, Winblad B, Fratiglion L. Mental, physical and social components in leisure activities equal- ly contribute to decrease dementia risk. Dement Geriatr Cogn Disord 2006;21:65-73

97. Abbott RD, White LR, Ross GW, Masaki KH, Curb JD, Petrovitch H Walking and dementia in physically capable elderly men. JAMA 2004;292:1447-53.

98. Rovio S, Kåreholt I, Helkala EL, Viitanen M, Winblad B, Tuomilehto J, Soininen $\mathrm{H}$, Nissinen A, Kivipelto M. Leisure-time physical activity at midlife and the risk of dementia and Alzheimer's disease. Lancet Neurol 2005;4:705-11.

99. Crowe M, Andel R, Pedersen NL, Johansson B, Gatz M. Does participa- tion in leisure activities lead to reduced risk of Alzheimer's disease? A prospective study of Swedish twins. J Gerontol B Psychol Sci Soc Sci 2003;58:249-55.

100. Andel R, Crowe M, Pedersen NL, Mortimer J, Crimmins E, Johansson B, Gatz M. Complexity of work and risk of Alzheimer's disease: a population-based study of Swedish twins. J Gerontol B Psychol Sci Soc Sci 2005;60:251-8.

101. Valenzuela MJ, Sachdev P, Wen W, Chen X, Brodaty H. Lifespan mental activity predicts diminished rate of hippocampal atrophy. PLoS ONE 2008;3:e2598.

102. Qiu CX, De Ronchi D, Fratiglioni L. The epidemiology of the dementias: an update. Curr Opin Psychiatry 2007;20:380-5.

103. Bäckman L, Small BJ, Fratiglioni L. Stability of the preclinical episodic memory deficit in Alzheimer's disease. Brain 2001;124:96-102.

104. DeKosky ST, Marek K. Looking backward to move forward: early detection of neurodegenerative disorders. Science 2003;302:830-4. 